\title{
Ecological distribution of snakes' fauna of Jazan region of Saudi Arabia
}

\author{
Mostafa Fathy Masood ${ }^{1 \& 2} *$ \\ 1-Department of biology, Faculty of Science, Jazan University, Kingdom of Saudi Arabia \\ 2- Department of Zoology, Faculty of Science, Al Azhar University (Assiut-Egypt) \\ *Email: m_f_masood@yahoo.com
}

\section{ABSTRACT}

This study was carried out in Jazan region in the Southwestern part of Saudi Arabia, bounded in the south and east by the Republic of Yemen, Asir area in the north and the Red Sea in the west.

The study area is one of the richest regions of the Kingdom of Saudi Arabia with animal biodiversity, where the region is characterized by the presence of a large group of wild animals that belong to different animal families. This work is devoted to the study of the biodiversity and geographical and ecological distribution of snakes found in the region.

The results showed that there are 36 species of eight families of snakes living in Jazan region; family Typholopidae represented by two species, while families Leptotypholopidae, Boidae and Atractaspididae represented by one species only respectively; whereas family Colubridae was the most represented one having 12 species, and family Elapidae was represented by three species. Family Viperidae was represented by six species and family Hydrophiidae represented by ten species. Nevertheless, this work concentrated on terrestrial snakes.

This work was suggested to throw light on the biodiversity of snakes' fauna in Jazan region as an important part of the ecosystem that has to be maintained. Since there are no enough studies on the animal species in the region.

The study included also the discussion of snakes that were ecologically surveyed in the study area according to: zoogeography and temporal distribution, mode of feeding, type of food and behavior.

Despite the fact that these snakes may be harmful to human life in some cases, it may also be useful to him in many aspects of life, the study showed the relationship between these snakes and human. It also threw light on the economical, medical, and scientific importance of these snakes as well as their importance for the process of environmental balance. The study presented some methods of the conservation of these species as one of the natural resources that must be maintained for not being a victim of extinction.

Key words: snakes, reptiles, ecology, biodiversity, conservation, zoogeographical distribution, behavior, status.

\section{INTRODUCTION}

Reptiles have generally a low ability to withstand changes in habitat and dispersal being particularly dependent on environmental condition for survival; they are therefore indicator species of habitat and climate. Few have actually evolved adaptation peculiarities to life in the Sahara desert (Abuzinada et al., 2004).

Snakes specially play an important role in the ecosystem. Also, they are important in the control of rodents and insects populations in the nature. Venomous snakes are economically and medically important. Venoms of some snake species 
fetch a large sum of money. On the other hand, anti-venom processing is important medically and economically.

Reptiles of Arabia were the point of interest of many authors, from different aspects. There are many studies done about reptiles of the kingdom. Some ecological studies have been undertaken on Saudi Arabian snakes and lizards. Certain authors have described small collections of reptiles from different regions in Saudi Arabia, including the Southern Hijaz (Parker, 1933 \& 1938 and Farag and Banaja, 1980); Eastern Arabia and Northeastern Arabia (Mandaville, 1965 \& 1967); Central Arabia (Schmidt, 1941 and Al-Wailly \& Al-Uthman, 1971) and Riyadh (Hussein, 1966). Mandaville, (1965); Gasperetti, (1974, 1988); Leviton (1977 a \& b); Al-Sadoon (1989, 1991); Okuda et al. (2001); Pough et al. (2004); Leviton et al. (1992); Mazuch (2004, 2005 a, b); Al-Sadoon and abdo (1991); Al-Johany and Al-Sadoon (1996); and Al-Sadoon (2010). These works studied reptiles in general.

Few studies dealt with snakes of Jazan region, but none of these studies presented a survey of snakes in the region. Therefore, this study is considered the first one that presents a detailed survey of Jazan snakes. This work was conducted to provide basic information, identification, abundance, ecological description, zoogeographical distribution, and status of snakes of Jazan, Saudi Arabia. This information is very important in studying snakes as very important natural resources that play a great role in the environmental balance. Snakes in the region have to be maintained and conserved, as most of them are victims of extinction.

\section{MATERIAL AND METHODS}

\section{The Study Area}

The present work was carried out in Jazan region. The region of Jazan is in the South-Western part of Saudi Arabia between longitudes $42^{\circ} \& 43^{\circ} .80^{\prime}$ and latitudes $16^{\circ} \& 17^{\circ}$, and is bounded on the South and east by the Republic of Yemen, Asir area in the North and the Red Sea in the West. Jazan region is away from the city of Riyadh with a distance of $1000 \mathrm{~km}$ and the holy city of Mecca with a distance of 500 $\mathrm{km}$. The region is distinguished with its ideally situated on the southern Red Sea coast with a coastline of almost $300 \mathrm{~km}$, and its towering green mountains in the Eastern region. The region is followed by several islands in the Red Sea, the most important and largest one is the island of Farasan. The estimated area of Jazan region is about $40000 \mathrm{~km}^{2}$ and this means that it occupies an area of $6 \%$ of the Kingdom of Saudi Arabia. Jazan Province includes about 5,000 villages and cities. Its major city, Jazan, is home to the Port of Jazan, Saudi Arabia's third most important port on the Red Sea. Other cities include Sabya, Abu Arish, Farasan, Ad-darb, and Samtah Fig. (1).

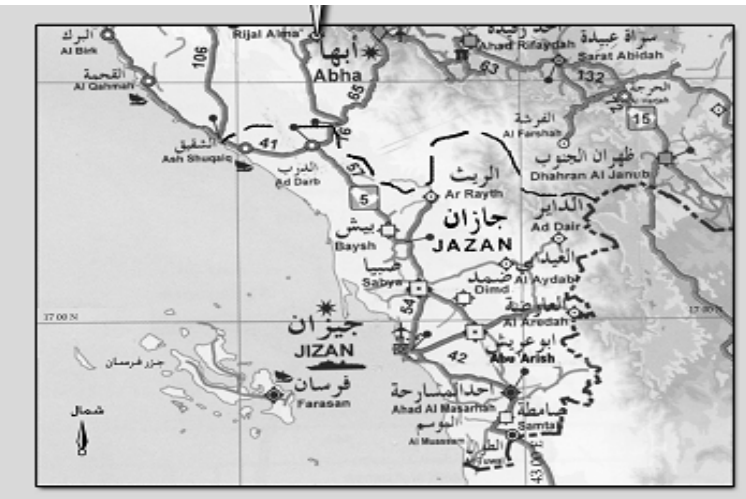

Fig. 1: Map of Jazan, Kingdom of Saudi Arabia 


\section{Climate and Topography of the Study Area}

Average temperature in January is about $23^{\circ} \mathrm{C}$ and in August about $33^{\circ} \mathrm{C}$, and the average relative humidity in January is $74 \%, 66 \%$ in August and $68 \%$ over the whole year. Rain fall in winter, spring and autumn, rate of fall is more than 600 $\mathrm{mm}^{3} / \mathrm{y}$ and more in the mountain areas. The rainfall on coasts of Jazan has a rate of more than $300 \mathrm{~mm}^{3} / \mathrm{y}$. As for the mountain regions in Jazan, the temperature degree is moderate in summer and so cold in winter and cool air almost throughout the year in mountainous areas and rainfall all over the year. Topography of Jazan is varied and distinguished. We find mountais, vallies, rocky and sandy deserts, semidesert, and cultivated lands. Climate and topography of Jazan make it includes different habitats that are suitable for oproximately all species of snakes.

\section{Surveying Snakes in the Study Area}

The survey of snakes of Jazan depended on the collected material, direct observations, and other indirect evidences such as tracks or burrows, while some information were based on records available in the literature. Field trips were carried out to different locations of Jazan region of Saudi Arabia. The most favourable time for collection is between March and July, when environmental conditions are most suitable for animals to emerge. Snakes were obtained by putting a hard stick on the head and pressing with stick on the snake head in such a manner that the snake could not move its head or its jaws, then, the snake was held with the thumb and forefinger just behind the head pulling of snakes out of holes or crevices by their tails many injure them seriously. Date, locality, Co-ordinates: latitude, longitude and altitude, have been recorded by a GPS (Table 1), time of day and other ecological information were recorded. Specimens in the collection were identified by standard keys (Marx, 1968; Leviton et al., 1992; Schleich et al, 1996). The status of each species was identified according to IUCN (2005).

Table 1: Co-ordinates: Latitude, longitude and altitude, of the studies area by a GPS

\begin{tabular}{|c|c|c|c|c|}
\hline \multirow[b]{2}{*}{ No } & \multirow[b]{2}{*}{ Location } & \multirow{2}{*}{$\begin{array}{c}\text { Co-ordinates } \\
\begin{array}{c}\text { Altitude } \\
\text { (meter) }\end{array}\end{array}$} & \multicolumn{2}{|l|}{ (a) } \\
\hline & & & Latitude & Longitude \\
\hline Site (1) & Al-Aradha & $200 \mathrm{~m}$ & $17^{\circ} 02^{\prime}$ & $43^{\circ} 05^{\prime}$ \\
\hline Site (2) & Sabya & $60 \mathrm{~m}$ & $17^{\circ} 10^{\prime}$ & $43^{\circ} 43^{\prime}$ \\
\hline Site (3) & Al-Darb & $100 \mathrm{~m}$ & $17^{\circ} 44^{\prime}$ & $42^{\circ} 16^{\prime}$ \\
\hline Site (4) & Al-Haredah & $60 \mathrm{~m}$ & $17^{\circ} 47^{\prime}$ & $41^{\circ} 57^{\prime}$ \\
\hline Site (5) & Zahban & $17 \mathrm{~m}$ & $18^{\circ} 06^{\prime}$ & $41^{\circ} 37^{\prime}$ \\
\hline Site (6) & Al-Khoba & $306 \mathrm{~m}$ & $16^{\circ} 47^{\prime}$ & $43^{\circ} 14^{\prime}$ \\
\hline Site $(7)$ & Ahad Almasarha & $55 \mathrm{~m}$ & $16^{\circ} 43^{\prime}$ & $42^{\circ} 57^{\prime}$ \\
\hline Site (8) & Abu-Arish & $65 \mathrm{~m}$ & $16^{\circ} 58^{\prime}$ & $42^{\circ} 49^{\prime}$ \\
\hline Site (9) & Sad Malaky & $180 \mathrm{~m}$ & $17^{\circ} 01^{\prime}$ & $42^{\circ} 58^{\prime}$ \\
\hline Site (10) & Bish & $183 \mathrm{~m}$ & $17^{\circ} 26^{\prime}$ & $42^{\circ} 32^{\prime}$ \\
\hline Site (11) & Wadi Jory & $472 \mathrm{~m}$ & $17^{\circ} 18^{\prime}$ & $43^{\circ} 04^{\prime}$ \\
\hline Site (12) & Wadi Laijab (Al Reth) & $390 \mathrm{~m}$ & $18^{\circ} 32^{\prime}$ & $42^{\circ} 59^{\prime}$ \\
\hline Site (13) & Al-Hakwo & $190 \mathrm{~m}$ & $17^{\circ} 29^{\prime}$ & $42^{\circ} 41^{\prime}$ \\
\hline Site (14) & Wadi kholb & $90 \mathrm{~m}$ & $16^{\circ} 43^{\prime}$ & $42^{\circ} 57^{\prime}$ \\
\hline Site (15) & Samtah & $50 \mathrm{~m}$ & $17^{\circ} 02^{\prime}$ & $43^{\circ} 05^{\prime}$ \\
\hline Site (16) & Al Rad & $220 \mathrm{~m}$ & $17^{\circ} 028^{\prime}$ & $42^{\circ} 58^{\prime}$ \\
\hline
\end{tabular}




\section{RESULTS}

\section{Species composition of Snake Fauna of Jazan}

The snake fauna of Jazan consists of 36 species belonging to eight families (Typhlopidae, Leptotyphlopidae, Boidae, Colubridae, Atractaspididae, Elapidae, Viperidae, and Hydrophidae). Terrestrial species consists of 26 species belonging to seven families. Families Leptotyphlopidae, Boidae and Atractaspididae are represented by a single species of each. Family Typhlopidae is represented by two species, while family Elapidae is represented by three species in two genera Walterinnesia and Naja. Family Colubridae was found to be the most widespread and distribution that it is represented by seven genera and twelve species (Lytorhynchus, Malpolon, Platyceps, Psammophis, Spalerosophis, Dasypeltis and Telescopus). Species of the former genus Coluber were updated and the newly adopted names (Platyceps) are included. Family Viperidae includes five genera (Cerastes, Echis, Bitis and Pseudocerastes) with six species (Table 2). Hydrophiidae represents $20.8 \%$ from total of snakes of Jazan. It includes 10 species, most of these species are poisonous snakes. Nevertheless, in this search concentrated on terrestrial snakes without concentrating on the aquatic Hydrophiidae species.

Table (2): Species Composition of terrestrial Snake Fauna of Jazan.

\begin{tabular}{|c|c|}
\hline Species & Common name \\
\hline \multicolumn{2}{|l|}{ Family : Typholopidae } \\
\hline Ramphotyphlops braminus (Daudin, 1803) & Bah dudi aswad \\
\hline Typhlops vermicularis (Merrem, 1820) & Greek blind snake \\
\hline \multicolumn{2}{|l|}{ Family : Leptotypholopidae } \\
\hline Leptotyphlops macrorhynchus (Jan, 1861) & Hook-billed Blind Snake \\
\hline \multicolumn{2}{|l|}{ Family : Boidae } \\
\hline Eryx jayakari Boulenger, 1888 & Jayakar's sand boa \\
\hline \multicolumn{2}{|l|}{ Family : Colubridae } \\
\hline Dasypeltis scabra (Linnaeus, 1758) & Egg-eating Snake, Rhombic Egg Eater \\
\hline Platyceps ventromaculatus Gray, 1834 & Glossy-bellied racer \\
\hline Platyceps rhodorachis rhodorachis (Jan, 1865) & Cliff racer Azrud jabali rafi. \\
\hline Platyceps elegantissimus (Günther, 1878) & Elegant racer \\
\hline Platyceps saharicus Shatti and McCarthy, 2004 & Saharan Cliff Racer \\
\hline Platyceps rogersi (Anderson, 1893) & Spotted racer \\
\hline Platyceps manseri Leviton, 1986 & Manser's racer \\
\hline Malpolon moilensis (Reuss, 1834) & Moila snake \\
\hline Spalerosophis diadema cliffordi (Schlegel, 1837) & Diadem snake, Clifford snake \\
\hline Telescopus dhara dhara (Forsskal, 1775) & Arabian cat snake \\
\hline Lytorhynchus diadema (Bibron and Dumeril, 1854) & Diademed Sand-snake \\
\hline Psammophis schokari schokari (Forsskal, 1775) & Schokari Sand Snake \\
\hline \multicolumn{2}{|l|}{ Family : Atractaspididae } \\
\hline Atractaspis microlepidota Gunther, 1866 & Burrowing adder \\
\hline \multicolumn{2}{|l|}{ Family : Elapidae } \\
\hline Naja haje arabica (Linnaeus, 1758) & Arabian Cobra \\
\hline Naja nigricollis nigricollis (Reinhardt, 1843) & Spitting Cobra \\
\hline Walterinnsia aegyptia Latasta, 1887 & Innes Cobra, Black desert cobra \\
\hline \multicolumn{2}{|l|}{ Family : Viperidae } \\
\hline Bitis arietans arietans Merrem, 1820 & Puff adder \\
\hline Echis pyramidum (E.\&I. Geoffroy St. Hilaire, 1827) & Carpet viper \\
\hline Echis coloratus Günther, 1878 & Burton's carpet viper \\
\hline Cerastes cerastes gasperetti (Leviton \& Anderson, 1967) & Greater cerastes Horned Viper \\
\hline Cerastes vipera (Linnaeus 1758) & Lesser Cerastes viper \\
\hline
\end{tabular}




Pesudocerastes persicus fieldi Schmidt, 1930
Systematic list
Class: Reptilia
Order : Squmata
Sub-order Ophidia (Serpents)
Family Typhlopidae
Genus Ramphotyphlpos Fitzinger, $\mathbf{1 8 4 3}$
Ramphotyphlops braminus (Daudin, 1803)
Common name: Bah dudi aswad, Brahminy blind snake.
Distribution: Africa and Asia, but being an introduced species in many parts of the
world, it is also found in Australia and the Americas. It is common throughout most of
Florida.

Distribution in Jazan : Sites $(1,2,3,4,5,6,7,8,9,10,13,14,15)$

Habitat and ecology: Usually occurs in urban and agricultural areas. These snakes live underground in ant and termite nests. They are also found under logs, moist leaves and humus in wet forest, dry jungle and even city gardens. The distribution and survival of this group of snakes directly reflects soil humidity and temperature. This is the most widespread snake species in the world, though looking more like a dark, shiny earthworm than a true serpent. Harmless and small (up to 170 millimeters total length). It derives its name from its habit of burrowing in soft moist soil in gardens.

Feeding : Their diet consists of the larvae, eggs, and pupae of ants and termites.

Status: Probably widespread and fairly common species. It is classified as Least Concern by IUCN (2005).

Genus Typhlops Oppel, 1811

Typhlops vermicularis (Merrem, 1820)

Common name: Greek blind snake, Bah doudy

Distribution: Southeast Europe, southwest Asia, East to Afghanistan and south to northern Egypt.

Distribution in Jazan : Sites $(1,2,8,9,10,11,14)$

Habitat and ecology: Usually occurs in open vegetated sandy terrain often with scattered stones. These snakes live in loose soil, underground in ant and termite nests. They are also found under logs, moist leaves and humus in wet forest, dry jungle and even city gardens. The distribution and survival of this group of snakes directly reflects soil humidity and temperature.

Feeding : Their diet consists of larvae and pupae of ants.

Status: Rare or uncommon and localized. It is classified as Least Concern by IUCN (2005).

Family : Leptotypholopidae

Genus Leptotyphlops Fitzinger, 1843

Leptotyphlops macrorhynchus (Jan, 1861)

Common name: Hook-billed Blind Snake, Beaked Thread Snake, Bah Sahrawi.

Distribution: Widely distributed from northeast Africa and Arabia to Pakistan, Turkey to the northwestern India (Leviton et al., 1992).

Distribution in Jazan : Sites $(1,2,3,4,5,6,8,11,13,14,15,16)$

Habitat and ecology: This snake was collected from a dry region with low annual rainfall, although, it was taken from under a rock with damp soil. Another specimen was collected from the sand-stone desert. Corkill (1932) reported that the Hook-billed Blind Snake is a nocturnal species. Habitats include river banks, coastal plain sands, and houses (Schleich et al., 1996). 
Feeding : Several authors reported the insectivorous diet for this species (Corkill, 1932; Schleich et al., 1996). Platyceps rhodorhachis was found to feed on this blind snake (Mulder, 2002).

Status: Probably widespread and fairly common species. It is classified as Least Concern by IUCN (2005).

Family:Boidae

Genus Eyrx Daudin, 1803

Eryx jayakari (Boulenger, 1888)

Common English name: Jayakar's sand boa, Al-Dassas (meaning the one that hides by burying itself in the sand).

Distribution:Widely distributed from North and East Africa to India and Central Asia Distribution in Jazan : Sites $(1,3,4,6,8,11,14,15)$

Habitat and ecology: Jayakar's sand boa can remain submerged in the sand and still observe surface prey, which includes geckos such as the Stenodactylus species, and Bunopus tuberculatus. Jayakar's sand boas are viviparous. An individual from Saudi Arabia laid seven eggs (six fertile), which hatched after 66 days incubation at $31-33^{\circ} \mathrm{C}$.

Feeding: Of this harmless species, it may also eat worm lizards.

Activity pattern : nocturnal and fossorial snake were excavated after tracing their tracks on the surface early in the morning. It is rarely seen. Its shape is adapted for burrowing and moving through soft sand.

Status: widespread and fairly common species. It is classified as Least Concern by

IUCN (2005).

Family Colubridae

Genus Dasypetltis Wagler, 1830

Dasypetltis scabra (Linnaeus, 1758)

Common name: egg eating snakes (Alfarigha).

Distribution: south Africa, south of sahara, known also from southwest Morocco , Egypt and southwest Arabia.

Distribution in Jazan : Sites $(1,2,4,7,9,13,15)$.

Habitat and Ecology : A species of wide ecological amplitude, occupying a variety habitats, with the exception of true desert and closed sandy desert with vegetation. Diurnal animals, very quick moving; often climb in bushes.

Feeding : Feeding mainly on lizards especially Acanthodactylus.

Status: Rare and localized. It is classified as Least Concern by IUCN (2005).

Genus Platyceps Blyth, 1860

Platyceps ventromaculatus (Gray, 1834)

Common name : The rat snake, Hardwicke's racer.

Distribution : extends from Palestine through Jordan, Iraq, Iran, Pakistan and India.

Distribution in Jazan : Sites $(1,2,3,4,5,7,9,10,12,13,16)$.

Habitat and ecology : It is non-venomous, diurnal. They prefer inhabited areas with water sources, such as farms and date gardens, where they subsist on rats.

Feeding : This snake feeds on birds, rats and lizards.

Status: widespread and fairly common species. It is classified as Least Concern by IUCN (2005).

Platyceps rhodorhachis (Jan, 1865)

Common name: Azrud jabali rafi, Jan's Desert-racer, Cliff Racer.

Distribution: Libya to northwestern India and Syria to the Arabian Peninsula.

Distribution in Jazan : Sites $(1,4,3,5,6,10,11,13,14,15,16)$ 
Habitat and ecology: It inhabits rocky areas in arid mountains region, wadis, ruins, often near oases and cultivation. Diurnal change to nocturnal activity during the hottest monthes.

Feeding: It feeds mainly on lizards. It feeds on skinks, Eumeces schneiderii, small mammals and birds (Schleich et al., 1996).

Status: Rather uncommon but widespread species. It is classified as Least Concern by IUCN (2005).

Platyceps elegantissimus (Günther, 1878)

Common name: Most Beautiful Whip Snake.

Distribution: Northwestern, central Arabia, Palestine and Jordan.

Distribution in Jazan : Sites $(1,3,5,6,11,15)$

Habitat and ecology: One specimen was found submerged in water. This species was collected from hard sandstone and rocky habitats. It is a nocturnal species.

Feeding: It feeds mainly on lizards.

Status: Rather uncommon but widespread species. It is classified as Least Concern by IUCN (2005).

Platyceps saharicus Shatti and McCarthy, 2004

Common name: Saharan Cliff Racer.

Arabic name: Azrud Gabali.

Distribution: From Libya through Egypt to Arabian Peninsula and eastward to Pakistan.

Distribution in Jazan : Sites $(1,2,3,4,5,6,7,8,9,11,13,15)$

Habitat and ecology: It inhabits arid rocky or stony areas preferring cliffs or canyons and sometimes it occurs near settlements at the borders of cultivated areas. Vertical distribution up to over $2000 \mathrm{~m}$. (Schleich et al., 1996). This snake inhabits especially rocky habitats, it moves over huge boulders with alarming speed. It has diurnal and crepuscular activity.

Feeding: It feeds on lizards and occasionally on birds.

Zoogeographical distribution: Palaearctic (Saharo-Sindian).

Status: Uncommon but widespread species. Classified by IUCN (2005) as Lower

Risk Least Concern (LC).

Platyceps rogersi (Anderson, 1893)

Common name: Spotted racer, Anderson's Whip Snake, Roger's Snake, Safartiel.

Distribution: Libya, Egypt, Palestine, Jordan, western Iraq and northern Saudi Arabia.

Distribution in Jazan : Sites $(1,2,3,4,5,6,7,8,9,10,11,13,14,15)$

Habitat and ecology: Stony or sandy desert hill areas where there is a certain amount of scrub-vegetation. Diurnal change to nocturnal activity during the hottest months. One specimen was found active at the study area at 9 o'clock at night on August $15^{\text {th }}$ in sandy vegetated habitat. It feeds mainly on lizards.

Feeding: This snake was found to feed on different lacertids, geckos, frogs, and toads (Schleich et al., 1996).

Status: Fairly common. It is classified as Least Concern by IUCN (2005).

Platyceps manseri Leviton, 1986

Common name: Manser's Black Racer

Distribution: Libya, Egypt, Palestine, Jordan, western Iraq and Saudi Arabia.

Distribution in Jazan : Sites $(1,3,4,6,7,8,10,11,13,14)$

Habitat and ecology: Stony or sandy desert. Diurnal change to nocturnal activity during the hottest months.

Feeding : It feeds mainly on lizards.

Status: Fairly common. It is classified as Least Concern by IUCN (2005). 
Genus Malpolon Fitzinger, 1826

Malpolon moilensis (Reuss, 1834)

Common name: Moila Snake.

Distribution: North Africa and south-west Asia.

Distribution in Jazan : Sites $(1,2,4,6,8,11,13,14,15)$

Habitat and ecology: Vegetated sandy desert. A diurnal snake, but becomes crepuscular in hotter weather. An effect of bite on human is more serious than other colubrid snakes.

Feeding : It feeds on lizards, snakes, small birds and rodents.

Status: It is classified as Least Concern by IUCN (2005).

Genus Spalerosophis Jan, 1865

Spalerosophis diadema cliffordi (Schlegel, 1837)

Common name: Diadem Snake, Clifford' Snake, Clifford's Royal Snake.

Distribution: North Africa south to Sudan east to Sinai, Palestine, Jordan, Syria, Iraq, Arabia and western Iran.

Distribution in Jazan : Sites $(1,3,9,10,12,14,16)$

Habitat and ecology: Sandy and stony desert. Nocturnal or crepuscular activity.

Feeding : It feeds on lizards and small rodents and birds.

Status: It is classified as Least Concern by IUCN (2005).

Genus Lytorhynchus Peters, 1863

Lytorhynchus diadema (Dumeril, Bibron and Dumeril, 1854)

Common name: Diademed Sand-snake.

Distribution: North Africa and South-west Asia.

Distribution in Jazan : Sites $(1,2,3,4,5,6,7,8,9,10,11,13,14,15)$

Habitat and ecology: Loose sandy areas. It is essentially nocturnal, but may become crepuscular in colder weather. It is assumed that it digs for lizards hidden in the sand.

Feeding: It feeds most frequently on animals inhabiting burrows or holes (Baha El Din, 1996). It seems to prefer nocturnal lizards, particularly geckos (Egan, 2007).

Zoogeographical distribution: Palaearctic (Saharo-Sindian).

Status: Lower Risk. It is classified as Least Concern by IUCN (2005).

Genus Psammophis Fitzinger, 1826

Psammophis schokari schokari (Forsskal, 1775)

Common name: Schokari Sand Snake.

Distribution: North Africa, eastward through Iran, into arid west Pakistan and India.

Distribution in Jazan : Sites $(1,2,3,4,5,6,7,9,10,11,13,14,15,16)$

Habitat and ecology: Sandy desert with vegetation. Diurnal animals, very quick moving, often climb in bushes.

Feeding : It feeds mainly on lizards, especially Acanthodactylus.

Status: It is classified as Least Concern by IUCN (2005).

Genus Telescopus Wagler, 1830

Telescopus dhara dhara (Forsskal, 1775)

Common name: North-African Cat Snake, the Tree cat Snake..

Distribution: North Egypt, Palestine, Jordan, the Arabian Peninsula.

Distribution in Jazan : Sites $(1,2,3,4,5,6,7,9,10,11,13,14,15,16)$

Habitat and ecology: This snake is usually an inhabitant of hamada areas and rocky hills. Males are noticeably shorter than females, 48 and $82 \mathrm{~cm}$ respectively. Females live on bushes and trees. They remain hanging motionless on tree branches. In contrast, males are strictly ground inhabitants.

Feeding : It feeds mainly on birds, however, young females feed on lizards.

Status: It is classified as Least Concern by IUCN (2005). 
Family: Atractaspididae

Genus: Atractaspis Smith, 1849

Atactaspis engaddensis Haas, 1950

Common name: Oasis Mole Viper or Burrowing adder, Hanash Aswad, El Abtar and Abo shenf, black snake.

Distribution: Sinai, Palestine, Jordan and southwestern and central Saudi Arabia.

Distribution in Jazan: sites $(1,3,10,13)$

Habitat and ecology : Nocturnal and fossorial burrowing species that is especially associated with oases and water sources. It is typically found in mountainous areas in Saudi Arabia. It is occasionally found in gardens. It prefers loose soil and avoids sand and very arid situations. It is found in dry bushland and olive groves. It is a burrowing snake but occasionally comes above ground. This snake spends most of its life underground. It is a very dangerous snake, which is known to have resulted in human mortality throughout its range.

Feeding: Active searcher,it feeds on rodents, amphibians, lizards and other snakes.

Zoogeographical distribution: Saharan and Ethiopian species.

Status: Rare and very localized, classified as Least Concern by IUCN (2005).

Family : Elapidae

Genus Naja Laurenti, 1978

Naja haje arabica (Linnaeus, 1758)

Common name: Arabian Cobra, Al-Cobra, Al-Nashir.

Distribution: Africa and Arabia.

Distribution in Jazan: sites $(1,2,3,4,5,6,7,8,9,10,11,12,13,14,16)$

Habitat amd ecology : It inhabits areas with at least some vegetation and water, never in deserts, semi desert, margin of deserts, in oases, wadis, on farmland near old wall or ruins, in ditches along roads and on hills with sparse vegetation. It was occasionally observed climbing on trees. Schleich et al. (1996) reported that mating is in early summer. It hides in loose soil, abandoned rodent burrows, old termite mounds or under rocks. Oviparous.

Activity : Diurnal, but Schliech et al. (1996) said that this species is mostly crepuscular and nocturnal, but it can often be seen active by day even during the hottest hours.

Feeding: Active searcher, it feeds on frogs, toads, fish, birds and small mammals.

Zoogeographical Distribution: Saharan and Ethiopian species.

Status: Widespread and common, threatened by intensive commercial collection. This species is near threatened. It is classified as Least Concern by IUCN (2005).

Naja nigricollis nigricollis (Reinhardt, 1843)

Common Name: Spitting cobra, Black-necked cobra, Al-Cobra, Al-Bakhakh.

Distribution: Africa and southwestern Asia.

Distribution in Jazan: sites $(1,3,5,6,7)$

Habitat and ecology : Vegetation areas, most dry areas, and semi-deserts. Diurnal activity. Feeding: Active searcher. It feeds on frogs, toads, fishes, birds and small mammals. Zoogeographical distribution: Saharan and Ethiopian species.

Status: Uncommon and localized in Saudi Arabia. This species is near threatened. It is classified as Least Concern by IUCN (2005).

Genus:Walterinnesia Lataste, 1887

Walterinnesia aegyptia Lataste, 1887

Common Name: Innes Cobra, Black desert cobra, Inne's cobra, Bargeel,Yaim, AlSul; meaning the Black one.

Distribution: Northeastern Egypt and southwestern Asia. 
Distribution in Jazan: sites $(1,3,5,6,7,10,15)$

Habitat and ecology : Rocky areas. Gasperetti (1988) added it is strictly nocturnal activity and fossorial, rarely coming to the surface of the ground.

Feeding: Active searchers. It seems that they prey mainly on Uromastyx sp.

Zoogeographical Distribution: Ethiopian species.

Status: Threatened. It is classified as Least Concern by IUCN (2005).

Family Viperidae

Genus Cerastes Laurenti, 1768

Cerastes cerastes gasperetti (Leviton \& Anderson, 1967)

Common Name: Greater cerastes Viper, Horned Viper, Haiya Al-Moqrana, Hayya umm jnaeb, or horned snake.

Distribution: This species is widely distributed throughout Africa to southwestern Asia. Marx (1968).

Distribution in Jazan: sites $(1,2,4,7,6,9,10,13,15)$

Habitat and ecology : Horned vipers are true desert snake, preferring sandy soil with some vegetation rocky outcrops as shelters. Nocturnal activity.

Feeding: Depending upon the availability of food, it has two ways in feeding strategies (Sit \& wait and active searcher feeding). It ranges long distances in search prey, which is mainly small birds (song-birds) or small mammals (Gerbillus, Mus and Rattus), Lizards and occasionally young or small snakes.

Zoogeographical Distribution: Palaearctic species.

Status: Widespread and common, threatened by intensive commercial collection. This species is near threatened in Saudi Arabia. It is classified as Least Concern by IUCN (2005).

Genus Echis Merrem, 1920

Echis coloratus Günther, 1878

Common Name: Burton's Carpet Viper, Haiya Ghariba, Al-ragta or spotted snake.

Distribution: Sinai, Israel and Arabian Peninsula.

Distribution in Jazan : sites $(1,2,3,4,5,6,7,8,9,10,11,13)$

Habitat and ecolgy: Strictly associated with vegetated rocky Wadis. Chiefly nocturnal, but it is also found basking in the early morning (in spring and autumn).

Feeding: It feeds on small frogs, toads, small reptiles and small rodents, but Schleich et al. (1996) found in its stomach a scorpion, a spider, termites and small beetles.

Zoogeographical Distribution: Saharan.

Status: Fairly common and widespread. Classified as Least Concern by IUCN (2005).

Echis carinatus (Schneider, 1801)

Common Name: Saw-scaled viper, Haiya Ghariba Samra.

Distribution: Throughout Africa, throughout southern Asia to India and Ceylon.

Distribution in Jazan : sites $(1,2,3,4,5,6,7,8,9,10,11,13,14,15)$

Habitat and ecolgy: Desert, semi deserts and sandy plains, sometimes in grassy terrain on cultivated land and gardens at the borders of oases. Mainly Nocturnal activity.

Feeding: Depending upon the availability of food, it has two ways in feeding strategies (Sit \& wait and active search feeding). It feeds on lizards, rodents, small birds, scorpions, small beetles, small frogs, toads, small mice, and rates.

Zoogeographical Distribution: Saharan.

Status: Uncommon, and much localized because it is often found in high densities. It is susceptible to intensive collecting by commercial animal collectors. This species is near threatened in Saudi Arabia. It is classified as Least Concern by IUCN (2005).

Bitis arietans arietans Merrem, 1820

Common Name: Puff adder, Haiya Al Nafasa. 
Distribution: This species is the most common and widespread venomous snake in Africa. Its geographic range includes: South Africa, Namibia, Swaziland, Morocco, Saudi Arabia, Oman, and Yemen.

Distribution in Jazan: sites $(1,3,5,6,7,13,14,15)$

Habitat and ecolgy: It is found in all habitats except true deserts, rain forests and mountain tops. The preferred habitats for the species include open grassland, savanna, open woodlands and rocky outcrops.

Feeding: Chiefly nocturnal, but it is also found basking in the early morning (in spring and autumn). It feeds on small frogs, toads, small reptiles and small rodents but Schleich et al. (1996) found in its stomach a scorpion, a spider, termites and small beetles.

Zoogeographical Distribution: Saharan.

Status: It is classified as Least Concern by IUCN (2005).

Cerastes vipera (Linnaeus, 1758)

Common name: Lesser Cerastes viper, Haiya El-Qaraa.

Distribution: North Africa to Arabia.

Distribution in Jazan: sites $(1,3,5,6,7,9,10,11,13,16)$

Habitat and ecolgy: Sandy desert particularly sand dune areas. Nocturnal activity.

Feeding: Depending upon the availability of food. It has two ways in feeding strategies (Sit \& wait and active search feeding). Feeding on lizards, rodents and small birds.

Zoogeographical distribution: alaearctic species.

Status: Uncommon, and much localized. Because it often found in high densities it is susceptible to intensive collection by commercial animal collectors. This species is near threatened in Saudi Arabia. It is classified as Least Concern by IUCN (2005).

Pesudocerastes persicus fieldi Schmidt, 1930

Common Name: Fields Horned - Viper, Haiya Moqarana Kaziba.

Distribution: Sinai, Palestine, Jordan northern Saudi Arabia and southwestern Iraq.

Distribution in Jazan: sites $(1,5,6,8,10,12,15,16)$

Habitat and ecolgy : Rocky areas. Nocturnal activity.

Feeding: Depending upon the availability of food, it has two ways in feeding strategies (Sit \& wait and active search feeding). It feeds on lizard, rodents and small birds.

Zoogeographical Distribution: Saharan (E).

Status: Rare but fairly widespread. Classified as Least Concern by IUCN (2005).

\section{DISCUSSION}

Snakes play an important role in the ecosystem that they reprsent. Snakes also, are important in the control of rodents and insect populations. Venomous snakes are important economically and medically. Venoms of some snake species fetch a large sum of money. On the other hand, anti-venom processing is important medically and economically.

Species richness

In spite of the secretive habits of most ophidian fauna and the difficulty in surveying these taxa, but we find that according to the variation of habitats existing in Saudi Arabia, it is one of the richest countries in biodivesity. It has a considerable biodivesity abundance, specially in snakes fauna. The study area has 36 species of snakes. This number indicates the richness of species and emphasizes the high ophidian 
diversity of the study area. A total of 26 species of teresstrial snakes have been recorded from Jazan region belonging to 7 families.

\section{Sruvey and criteria}

Sruvey, and criteria of snakes in the study area have been shown in table (3). According to the table, we found that the single Leptotyphlopidae is Rare. There is limited information on its distribution and numbers. The two typhlopids are moderate in distribution and numbers. Of the 12 Colubrids, five are widespread, two moderate in distribution and number, three have limited information on distribution and number and three are Rare. The single Atractaspidid is Rare and need special attention in some areas. Of the three elapids, two are moderate in their distribution and need special attention in some areas and the other is Endangered and needs special attention in some areas. Of the six viperids, one is widespread, three moderate in distribution and number, one is moderate in distribution and number and needs special attention in some areas, and one has limited information in distribution and number. From the above, we note that the future of snakes of the area is not clear. There are five rare species and need protection, i.e. Ramphotyphlops braminus, Coluber elegantissimus, Dasypeltis scabra, Telescopus dhara, Atractaspis microlepidota, and one is endangered (Walterinnesia aegyptia). All recorded species were listed by IUCN categories as Lower Rick, Least Concern (IUCN 2005).

Table 3: The sruvey and criteria of terrestrial snakes in the study area.

\begin{tabular}{|l|l|c|}
\hline \multicolumn{1}{|c|}{ Scientific name } & \multicolumn{1}{c|}{ Common name } & Criteria \\
\hline Eryx jayakari Boulenger, 1888 & Jayakar's sand boa & $(2,3,5)$ \\
\hline Platyceps ventromaculatus Gray, 1834 & Glossy-bellied racer & $(5,7)$ \\
\hline Platyceps rhodorachis rhodorachis (Jan, 1865) & Cliff racer & $(3,7)$ \\
\hline Platyceps elegantissimus (Günther, 1878) & Elegant racer & $(2)$ \\
\hline Platyceps manseri Leviton, 1986 & Manser's racer & $(3,5)$ \\
\hline Malpolon moilensis (Reuss, 1834) & Moila snake & $(5)$ \\
\hline Spalerosophis diadema cliffordi (Schlegel, 1837) & Diadem snake & $(2,7)$ \\
\hline Telescopus dhara dhara (Forsskal, 1775) & Arabian cat snake & $(1)$ \\
\hline Atractaspis microlepidota Günther, 1866 & Burrowing Asp & $(1,2,5)$ \\
\hline Naja haje arabica Scortecci, 1932 & Arabian cobra & $(1,3)$ \\
\hline Walterinnesia aegyptia Lataste, 1887 & Black desert cobra & $(5)$ \\
\hline Bitis arietans arietans Merrem, 1820 & Puff adder & $(1,2)$ \\
\hline Echis pyramidum (E.\&I. Geoffroy St. Hilaire 1827) & Carpet viper & $(1,2)$ \\
\hline Echis coloratus Günther, 1878 & Burton's carpet viper & \\
\hline
\end{tabular}

The following are the key taxa that have been included in the updated System Plan for Saudi Arabia. Species were selected by applying the following set of criteria and the numbers in the species lists refer to which criterion or criteria qualify particular organisms for inclusion as "key taxa".

1). Species that are critically endangered, endangered, or vulnerable (globally, regionally, or nationally); taxa which are locally extinct in the wild may be included, provided that there is an NCWCD policy to reintroduce them.

2). Species that are endemic to the Arabian Peninsula, the Red Sea, or the Gulf.

3). Species of which the conservation of populations within Saudi Arabia is essential to the conservation of the taxon (near-endemics and migrants for which Saudi Arabia represents a critical range).

4). Relict species, or subspecies that are of global, regional, or national significance.

5). Species of special ecological importance (i.e. fulfilling a vitally important function in an ecosystem such as providing a key habitat for other species, serving as indicator species, etc.).

6). Species of significant economic importance.

7). Species that serve a "flagship" function (i.e. high-profile species of cultural value, the protection of which will also protect large numbers of other species that share their habitats).

Endemic snakes include Jayakar's sand boa, the elegant racer and Manser's racer, the two carpet vipers, and the native subspecies of the cat snake, cobra, and puff adder. The black desert cobra is a near endemic. The sand boa is essential to the ecosystem of the sand seas, while large predatory snakes such as the Arabian cobra, 
moila snake, diadem snake, and glossy-bellied racer play important ecological roles. The latter three species are important predators of rodents. The venomous burrowing asp, cobras, carpet vipers, and puff adder are all relentlessly persecuted, and are likely to come under increasing pressure from collection for their venom, which fetches a high price in the pharmaceutical market.

\section{Threats and Conservation Methods}

Several factors appear to have signficant effect on the population of snakes. These include commercial exploitation, habitat destruction, environmental pollution, the wrong blief of some people and the bad image of snakes in the mind of most people make all the species victims of humans. Most people will kill any snake they encounter without any hesitation hence they are avoided.

The main threat face the snakes of the area is habitat loss, degradation and fragmentation. Many areas were changed illegally to cultivated areas which cause habitat loss of many species, habitat degradation by changing the area to monotypic area and the decline of biological diversity in different levels including the diversity of fauna, flora and habitats. Those activities cause as well habitat fragmentation and form barriers for the diversion and genetic diversity of these fragile taxa of reptiles of the known poor ability of diversion. Also, the cultivation activities caused extension of the distribution range of some species. Using of fertilizers and pesticides may cause ultimate threat to the reptile fauna generaly of the area and the whole ecosystem as well. Quarrying activities in the area cause habitat loss of many reptile species.

\section{Conservation}

Conservation of these taxa should be done by several steps which must be taken by both governementl and non-governemental organizations. These steps are represented in preventing or organizing all reasons of habitat loss and distuction; sustainable utilization of reptile resources; puplic awarness and conservation education to local people about reptiles "snakes " and their importance; captive breeding programmes and protected areas systems; preventing all kinds of commercial exploitation in the adjacent areas; the necessity of consultation of socioeconomic specialists. More systematic research and basic taxonomic work, and more ecological, demographic and behavioural research are needed to help in developing strategies for conserving reptiles and snakes, especially the most endangered species, in addition to more widespread application of scientific knowledge and techniques to conservation. Professionally trained conservationists and biologists in governmental decision-making posts, parks and protected-areas management, and for the growing local nongovernmental conservation organization.

\section{REFERENCES}

Abuzinada, A.H., Robinson, E.R., Nader, I.A. and Al Wetaid, Y.I. (2004): First Saudi Arabian National Report on the convention on Biological diversity. The National commission for Wildlife conservation and development, Riyadh. Riyadh. Saudi Arabia pp. 27-28.

Al-Johany, A.M. and Al-Sadoon, M.K. (1996): Selected body temperature and metabolic rate-temperature curves of three species of desert snakes. J. Arid Environ. UK. 34: 363-370.

Al-Sadoon, M.K. (1989): Survey of the reptilian fauna of the kingdom of Saudi Arabia I-The snake fauna of the central region J. King Saud Univ.1 A, Science (1): 5369. 
Al-Sadoon, M.K. (1991): Metabolic rate-temperature curves of the Horned Viper, Cerastes cerastes gasperetti, the Moila snake, Malpolon moilensis and the Adder, Vipera berus. Comp. Biochem. physiol., 99A (1/2): 119-122.

Al-Sadoon M.K. (2010): Reptiles Diversity in Al-Hassa Region of Saudi Arabia. J. Egypt. Ger. Soc. Zool. Egypt Vol. 58.

Al-Sadoon, M.K. and Abdo, N.M. (1991). Fatal envenoming by the snake Atractaspis newly recorded in the Central Region of Saudi Arabia. J. King Saud Univ., 3, Science (2):123-131.

Al-Wailly, A.J. and Al-Uthman, H.S. (1971): Some lizards from Central Saudi Arabia. Bull. Iraq Nat.Hist. Mus. (5) (1): 39-42.

Corkill, N.L. (1932): The snakes of Iraq. - Journal of Bombay Natural History Society, 35: $552-572$.

Egan, D. (2007): Snakes of Arabia; "A field guide to the snakes of the Arabian Peninsula and its shores". Motivate publishing.

Farag, A.A. and Banaja, A.A. (1980): Amphibians and reptiles from the western region of Saudi Arabia. Bull. Sci. K. A. U., 4: 5-29.

Gasperetti, J. (1974): A Preliminary Sketch of the Snakes of the Arabian Peninsula. $J$. Saudi Nat. Hist. Soc., 12(1974), IV+72 pp.

Gasperetti, J. (1988): The Snakes of Arabia. Fauna of Saudi Arabia, 9: 169-450.

Hussein, M.F. (1966): On the reptiles of Riyadh and its surroundings in Saudi Arabia. 5th Arab Sci. Congr. Baghdad.: 479-485

IUCN (2005): Global reptile assessment. Species accounts for Mediterranean species.

Leviton, A.E. (1977a): A New Lytorhynchid Snake. J. Saudi Nat. Hist. Soc., 19: 16-25.

Leviton, A.E. (1977b): On the Status of Natrix dubbiosi scortecci. J. Saudi Nat. Hist. Soc. 19: 26-29.

Leviton, A.E., Anderson, S., Adler, K. and Mimton, S. (1992): Handbook to Middle East amphibians and reptiles. Society for study of Amphibians and reptiles, Oxford, Ohio.

Mandaville, J.P. (1965): Plants Eaten by Uromastix microlepis Blandford and other Notes on these Lizards in Eastern Arabia. J. Bombay Nat. Hist. Soc. 61(10) 161163.

Mandaville, J.P. (1967): The Hooded Malpolon moilensis Reuss and Notes on other Snakes of North-Eastern Arabia. J. Bombay Nat. Hist. Soc., 64(1): 115-117.

Marx, H. (1968): Checklist of the reptiles and amphibians of Egypt. Spec. Publ. U.S.A. Naval Med. Res. Unit No. 3, Cairo.

Mazuch, T. (2004): Biologie a taxonomie zmije Echis pyramidum v Keni. Herpetologické informace, 1: 10-11.

Mazuch, T. (2005 a): Taxonomie a biologie zmije Echis pyramidum leakeyi z Keni. Akva Tera Fórum, 1(1): 64-71.

Mazuch, T.(2005 b): Taxonomie a biologie zmije rodu Echis Merrem 1820. Akva Tera Frórum. 1-15.

Mulder, J. (2002): The thread snake, Leptotyphlops macrorhynchus (Reptilia: Leptotyphlopidae) as a presumed prey item for the racer Coluber rhodorachis (Reptilia: Colubridae). Zoology in the Middle-East, 26: 89-92.

Okuda, D., Nozaki, C., Sekiya, F. and Morita, T. (2001): Comparative Biochemistry of Disintegrins Isolated from Snake Venom: Consideration of the Taxonomy and Geographical Distribution of Snakes in the Genus Echis. J.Biochem., 129:615620.

Parker, H.W. (1933): Reptiles and amphibians, In: H. St. J.B. Philby, The Empty Quarter. London: Constable, 397-398. 
Parker, H.W. (1938): Reptiles and Amphibians from Southern Hejaz. Ann. Mag. Nat. Hist. (Set. 11) 1(5): 481-492.

Pough, H., Andrews, R., Cadle, J., Crump, M., Savitzky, A. and Wells, K. (2004): Herpetology, 3rd Edit., Person Education, Inc., 762 p.

Schleich, H.H., Kästle, W. and Kabisch, K. (1996): Amphibians and reptiles of North Africa. Scientific Books Germany.

Schmidt, K.P. (1941): Reptiles and Amphibia from Central Arabia. Field Mus. Nat. Hist. Zool. Ser. 24(16): 161-165.

\section{ARABIC SUMMARY}

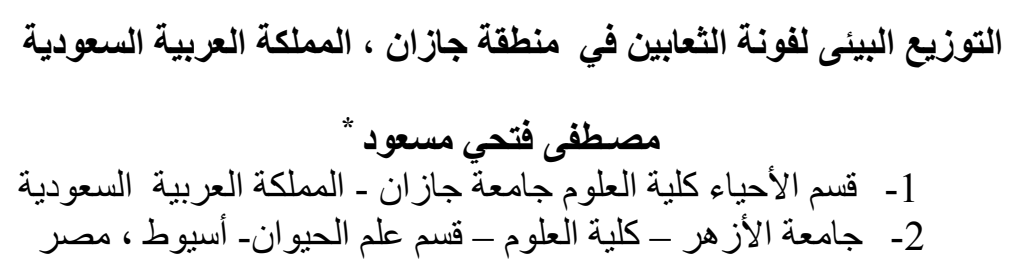

أجريت هذه الدر اسة في منطقه جاز ان ، التي تقع في الجنوب الغربي للمملكة العربية السعودية

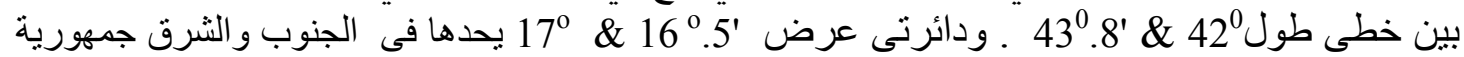

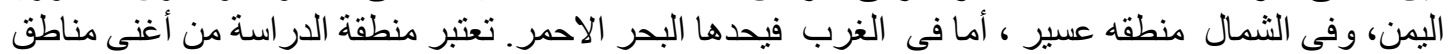

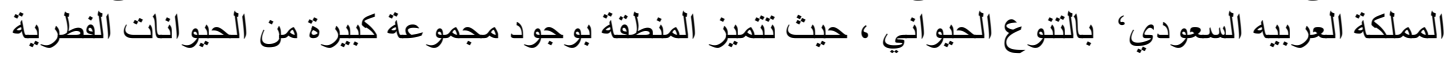

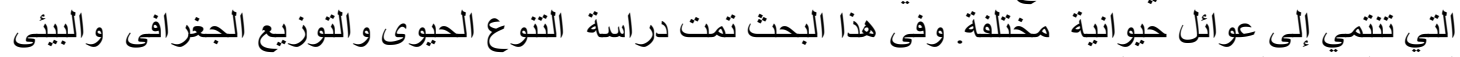
لفونة الثعابين التى تقطن المنطقة

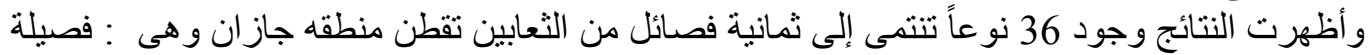

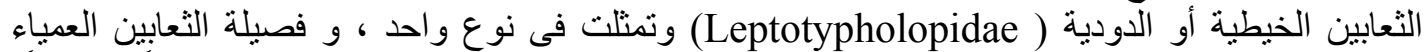
(Colubridae) ويمثلها نو عان. وكانت فصيلة الثعابين الحقيقية (Typholopidae)

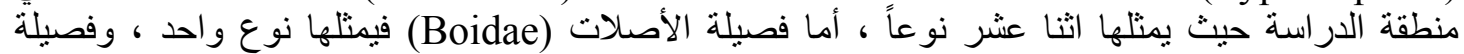

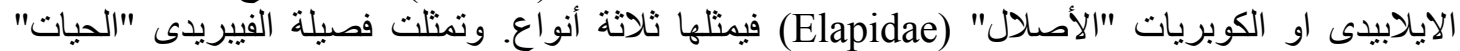

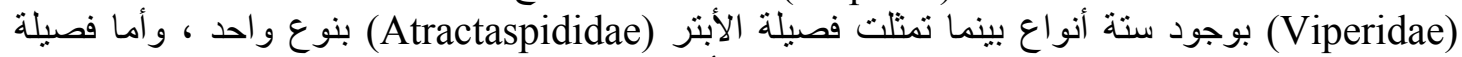

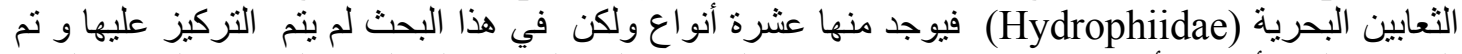

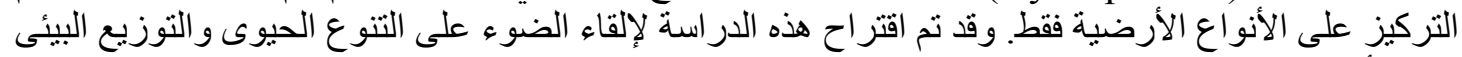

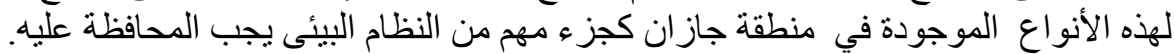

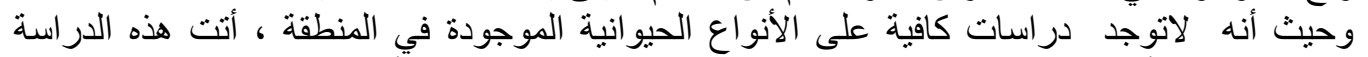

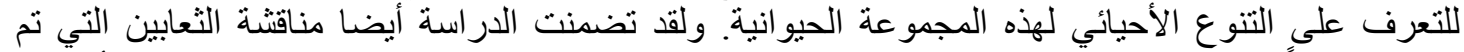

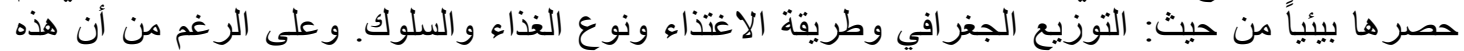

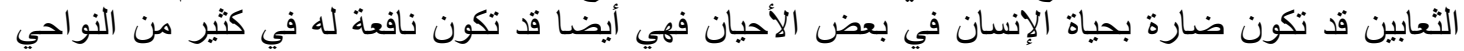

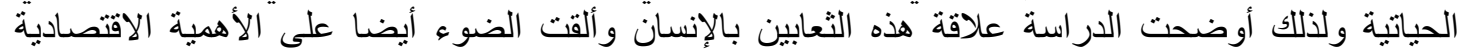

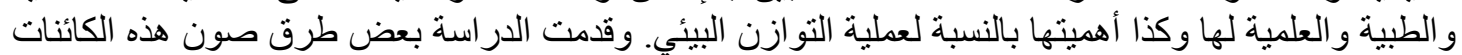
كأحد المصادر الطبيعية التي لابد من الحفاظ عليها حتى لا تتعرض النية للانقر اض. لاض. 